\title{
The Development of Responsible and Sustainable Business Practice: Value, Mind-Sets, Business-Models
}

\author{
Mollie Painter ${ }^{1,2}$ (1) $\cdot$ Sally Hibbert ${ }^{3} \cdot$ Tim Cooper $^{4}$
}

Received: 11 June 2018 / Accepted: 14 June 2018 / Published online: 27 July 2018

C) Springer Nature B.V. 2018

The main goal of this Special Issue (SI) of the Journal of Business Ethics is to explore the changes in values and mindsets that are required for new, sustainable and ethical business models and consumption practices to flourish. Notable manifestations of efforts to embody an ethical perspective within business practices are seen in recent attempts to rethink business models (Bocken et al. 2014; Linder and Williander 2015) and to develop hybrid organizations (e.g., social enterprises) and collaborations (Defourny and Nyssens 2006) more likely to balance economic, social and environmental needs. Changes in consumption range from selecting more ethical and sustainable options, e.g. fair trade and renewable energy (De Pelsmacker and Janssens 2007; Bang et al. 2000) and slowing the acquisition and replacement of goods (Cooper 2005, 2010) to more radical shifts in lifestyles such as voluntary simplicity (Marchand et al. 2010; Shaw and Riach 2011). It is widely recognized that embedded practices and beliefs constrain change, but there is a keenness to investigate the emergence of business and consumption practices that shift away from traditional resourcedepleting forms of capitalism. We are delighted to guest edit this special issue and present a set of papers that illustrates

Mollie Painter

mollie.pm@ntu.ac.uk

Sally Hibbert

sally.hibbert@nottingham.ac.uk

Tim Cooper

t.h.cooper@ntu.ac.uk

1 Responsible and Sustainable Business Lab, Nottingham Business School, Nottingham Trent University, Shakespeare Street, Nottingham, UK

2 IEDC-Bled School of Management, Prešernova cesta 33, 4260 Bled, Slovenia

3 Nottingham University Business School, University of Nottingham, Jubilee Campus, Nottingham, UK

4 Architecture, Design and Built Environment, Nottingham Trent University, Shakespeare Street, Nottingham, UK the appetite to generate this insight by examining diverse forms of enterprise and consumption, evidencing efforts to embed more responsible and sustainable approaches. Though the papers vary in the conceptual lenses that they adopt, the trend towards a process-based perspective of valuation is evident among them. Hence, we start our editorial by articulating some of the changing conceptions of value and the potential to explore how evolving mind-sets and mental models can influence responsible and sustainable business.

New articulations of 'value' have been emerging for a few decades now (Muniesa 2011; Helgesson and Kjellberg 2013), creating a plethora of new vocabularies in their wake (Painter-Morland et al. 2018). The potential of these beliefs and concepts to encourage ethical and sustainable enterprise is still open to debate (Dubuisson-Quellier 2013). Research is therefore needed to critically interrogate the validity of the new concepts that attempt to articulate changing beliefs about the value of responsible and sustainable business and consumption. The reality is that sedimented practices that result from capitalist growth ambitions, consumption patterns, financial systems and other aspects of the broader political economy still perpetuate unethical and unsustainable practices. We are therefore interested in how certain mind-sets have emerged (Werhane 2008) and how these are sustained or changed within contemporary environments. The goal of this collection of papers is to go beyond theory in studying the ways in which these mind-sets become embodied practices, shaping our lifestyles as well as our ethical or unethical behaviour through everyday habits, intuitions, and emotions. What emerged from the SI call and the editorial review process is a series of papers that help us to address some, but not all of these questions. In this editorial, we contextualize the papers with reference to a broader philosophical debate in the business ethics and sustainability field, specifically philosophical pragmatism, and highlight the need for future research to explore these questions to better understand how they shape the course of transition. 


\section{Value and Valuation}

An important theme within some of the papers in the SI relates to their employment of philosophical pragmatism (also known as American pragmatism) as a key to understanding the way in which valuation has come to operate in business and society debates. A recent publication by Philippe Lorino (2018) meaningfully summarizes the relevance of pragmatism for organizational life and, as such, offers a helpful philosophical framework for this SI. Even the papers that make no explicit mention of pragmatism share some of its epistemological and ontological assumptions around agency and the nature of enquiry. It is therefore worthwhile to provide a short overview of some of the key beliefs of pragmatism, and to consider its potential impact on responsible and sustainable business practices. The important contribution that pragmatist conceptions of valuation make is that they rid us of the idea that value reflects the objective scientific or physical characteristics of objects or situations (Lorino 2018; Muniesa 2011). Nor do they reflect affective manifestations of the preference of isolated human subjects. If 'value' is then neither an objective truth nor a subjective affection, how should it be defined? And what are the implications for underpinning sustainable and responsible business?

A growing body of scholarship draws upon the ideas of Dewey (1922 [1957]) to argue that value is the result of the social process of action (Lorino 2018; Winter 2013; Cohen 2007). It is therefore something that comes into existence through doing, rather than thinking. Being the result of situated practices, 'value' is also subject to time-space variables and depends on the strategic context and narrative accounts of actors engaged in activity (Lorino 2018). This is important not just for understanding how different types of businesses can be valued and how different types of value are created for society, but also how valuation operates within consumption practices and other dimensions of everyday business (Helgesson and Kjellberg 2013). Pragmatism offers us the means to critique current forms of capitalism and their tendency to undermine freedom as self-realization. Instead of an individualist 'freedom from constraint', self-realization is intersubjectively constituted through forms of social cooperation that allow each person to meaningfully fulfil social obligations and contribute to the whole (Visser 2017). Forms of capitalism that undermine this broader social perspective therefore have to be critiqued and replaced. It is from this perspective that pragmatism can sharpen business ethics' critical edge and generate viable and liberating alternatives to unsustainable forms of capitalism.

The importance of context and narration within a pragmatist paradigm does not render value a relativistic notion, subject to the whims of whoever is interpreting it. Neither is it something that can easily be objectively measured and described. Instead, to judge or appraise 'value' is in itself a valuation process, a 'performance', rather than the application of value measurements. The two meanings of value, i.e. 'prizing' and 'appraising', fuse within the pragmatist account of value (Dewey 1944), as both can only make sense in terms of a prized end which has to be effectively reached and, as such, valuation is part of the continuous design and engineering of social activity (Lorino 2018). It enacts a future. It is this sense, that valuation is absolutely key to the promotion of sustainable and responsible business-sustainable possibilities are enacted in and through the valuation process.

If we believe that a sustainable future is prized, and that responsible business is a practice worthy of pursuit, our valuations should enact and serve this end. For instance, in a business context in which short-termism persists, the valuation of intangibles may play an important role in engineering a different future (Sewchurran et al. 2018). A pragmatic approach to strategic planning enables a problem (such as environmental degradation) to be addressed by reflecting on past experience and generating new disruptive data that allow for new working hypotheses and principles to emerge. These may then be experimented with to either deny the new principles or, alternatively, to amend or modify previous beliefs and practices in view of valuable experiences in the future (York 2009). The intuitive, imaginative and experimental character of pragmatist enquiry means that it cannot be done at arms-length, but requires participative involvement. This may explain how so-called 'objective fact' and 'logical argument' often fail in supporting responsible and sustainable business practice.

But how are we to go about this, given the proclivity of management and organizational sciences to binary distinctions between facts versus values, and objective versus subjective analyses? Is it not perhaps the case that current management practice is so wedded to its belief in the rational subject capable of objective evaluation that an alternative conception is bound to meet with rejection and failure? This is certainly the risk that Moosmayer et al. (2018) point to in their analysis of the paradoxes inherent in management education. They do, however, also gesture towards the pragmatist alternative, which entails the freedom springing from reflective inquiry with regard to desired social ends. In terms of method, pragmatists tend to opt for narrative, arguing that it allows us to construct the relationships between things which allow for a certain reality to come into existence.

We also need to reconsider our tools of valuation and make sure that they match the evolving beliefs we have about prized ends. Understanding the 'value spill-over' in an organization like Cafédirect, for instance, provides an interesting instantiation of how conceptions of valuation 
play out in practice (Davies and O'Doherty 2018). There must be an openness to what Lorino (2018, p. 244) calls 'in vivo valuation', which involves collectively building a narrative in situation, leading to some temporary and hypothetical compromise, and some contingent and falsifiable value judgment. The way in which professional identities evolve in relation to new narrative understandings that are collectively built would play an important role here (De Graaf 2018). Some of the papers in the SI provide inspiration for inquiry into these issues.

\section{Inquiry}

An important part of pragmatist epistemology is the belief that the knowable world does not exist 'out there' as a series of objective facts that can be discovered through researchers' impartial scrutiny. Instead, 'knowing' is a process of experimenting with active constructions of possible meanings in and through a situated process of action. Pragmatist inquiry is not aimed at representing the world, but rather offering mediating signs, which are social concepts insofar as they allow intersubjective relationships to emerge. Mediation is for pragmatism an existential rather than merely cognitive process, and employs social rather than psychological concepts (Lorino 2018). Mediating signs are material, and over time become socially loaded through experience (Onyas and Ryan 2014). They are not static 'pictures' of a reality 'out there'. Yet they are not random at all, but rather social meaning-making which affords directionality to action.

It is in this regard that habituation plays an important role. Habits are at their root dispositional and social, rather than behavioural. They emerge socially, not only within individuals as some philosophical and organizational accounts may suggest (Ravaisson 2008; Grosz 2013; Painter-Morland and Deslandes 2014). Through language, we segment what is essentially an ongoing flow of action into partially stabilized and socially shared segments of meaning, which are then called habits (Woolsey Biggart and Beamish 2003; Lorino 2018). Because pragmatist experimentation is both oriented toward past and future simultaneously, it can direct us towards actions required by a specific time and space. As Lorino (2018, p. 80) so succinctly explains: "habit is the enacted relationship between experience and expectation". This perspective offers us insight into the tensions that may emerge within hybrid organizations, and also why it is so difficult to fundamentally shift traditional business education in the direction of promoting responsible and sustainable business. For example, leaders' particular experiences in running social enterprises cannot easily be replaced or mimicked by executives coming from more commercial backgrounds (Davies and O'Doherty 2018), and professionals' predominant mental models may create certain blind-spots or blockages that would benefit from the freedom that reflective practice allows (De Graaf 2018). Thinking about the demands of hybridity may prompt the question: should we not be redesigning our curricula to be more accommodating and supportive of hybrid business models?

Pragmatists also highlight the important role that abduction (as opposed to the typical alternatives of deduction and induction) plays in inquiry. Abduction is the process whereby a tentative 'working hypothesis' emerges through problem-solving action in the world. Though it draws on past experience, it does not operate in the way that hypotheses do in deductive research (Fann 2012), because a hypothesis emerging as a result of abduction is not directly testable (Lorino 2018). Instead it is a kind of narrative bridge that connects imagination with logical reasoning. In the empirically oriented papers in this SI, we see the importance of narration in making sense of the problem-solving operative in various organizations. Most papers also underscore the role that long-term observation of the dynamics in specific social contexts plays in identifying emergent themes.

The pragmatist conception of inquiry therefore forms a helpful backdrop against which to understand the methodological approaches employed by a number of the papers in this volume. For instance, the value of longitudinal case study analysis for understanding what pragmatists would refer to as 'trans-action' (not to be confused with the colloquial use of the term) is evident from the analysis of hybrid collaboration and hybrid business models seeking triple bottom-line performance.

\section{Trans-action}

In line with their rejection of all other binary oppositions, pragmatists try to get rid of the individual versus collective dualism by describing all human beings as thoroughly relational, engaged in the process of trans-acting with others and things on an ongoing basis. It is important to note that the relationship is privileged over the individual within pragmatism, as 'the self' is always already a knot of multiple 'selfpositions' (Lorino 2018, p. 149). Trans-action should also not be confused with the transactions between two distinct individuals or groups. Instead it depends on the process of emergence by which concepts, names, categories and boundaries are continually questioned in view of the existential problem that needs to be solved. Allowing for difference is key to this process of emergence. Pragmatism provides important notions within business ethics, such as stakeholder theory, with a democratic and ethical base. As Jensen and Sandström (2013) explain, a fallibilistic stakeholder pragmatism allows us to consider how value is created contingently, as an ongoing response to procuring certain social 'ends-inview' (Dewey 1939). 
These insights of course resonate strongly with the process philosophy-turn in organizational studies (Helin et al. 2014). Though there are multiple parallels, Lorino is keen to point out difference between the pragmatist view of organization and that of Bergson (1965), who is one of process philosophy's central figures. Most notably, Bergson's (1965) account of self, habituation and process is much more focused on the individual (Painter-Morland and Deslandes 2014). By contrast, the focus within pragmatism is on a community of trans-actional inquiry, which involves contemplating the emergence of new professional practices and identities to respond. Habituation is a residue of our belonging to communities, and being engaged in creating social purposes through ongoing problem-solving and narration. We have similarly seen the ascendency of ideas inherent to pragmatism in research on sustainable consumption, as the field has shifted attention from examining individual choice of offerings such as fair trade or organic food, renewable energy and hybrid cars (Bang et al. 2000) to exploring the complex and dynamic processes involved as more sustainable forms of consumption emerge and take on meaning within social groups and communities. A prominent stream of scholarship in this vein has focused upon movements towards radical lifestyle changes such as voluntary simplicity that reflect ecological principles of sustainability (Marchand et al. 2010; Shaw and Riach 2011; Walther and Sandlin 2013). Pragmatism is also helpful to understand less dramatic shifts towards sustainable consumption practices, for highly symbolic and very ordinary goods and services, and the ways that they interconnect with transitions in the socio-technical systems around their provision (Brand 2010). While detailed discussions of pragmatism's perspectives on consumption are still relatively rare, Hiller and Woodhall's analysis (2018) offers important perspectives on the meaning-creation processes and the emergence norms and routines that interact to inform consumption practices.

It is important to note that a pragmatist perspective does not operate from the vantage point of fixed, universal and eternal principles, but rather requires an iterative, case-bycase analysis of the social consequences that are at stake (Jacobs 2004). The existential purpose behind sustainable and responsible business functions as an end-in-view i.e. it is not a final telos to pursue, but a desirable, prized future that offers a response to the problems and challenges we face in the present. It is therefore not entirely surprising that many papers in this SI may not read like traditional 'ethics' papers, but instead offer in-depth analysis of contextual practices from which certain normative implications clearly emerge. We believe that some of the papers provide useful insights into the types of narrative frames, identities and professions or roles that may be part of this continual emergence towards responsible and sustainable business. The relational ontology that pragmatism advocates is particularly helpful in understanding the business models operative in social enterprises and hybrid organizations, as evident in several papers in this volume.

\section{Overview of Papers in this Volume}

In what follows, we offer a brief overview of the papers in this Special Issue and provide some perspectives on how they may stimulate further research on responsible and sustainable business practice.

The paper by Hiller and Woodhall (2018) explicitly adopts a pragmatist ontology, taking a fresh view of theories of value that have been applied to ethical consumption. They trace developments in the literature from cognitive perspectives that emphasize value trade-offs and consumer problem-solving through to socio-cultural conceptions that view values to underpin everyday practices inherent to lifestyle. In contrast to these perspectives, which focus on the motivational aspect of pre-existing values, the authors concentrate on understanding the formation of values through processes of reflection. They draw upon John Dewey's philosophical stance and embrace the ontological position that value emerges from experience, shaped by existing valuations and experiences that feed into iterative and cumulative interpretations. They follow Dewey in espousing an 'endin-view' conception of value and draw upon their empirical study of fashion consumption to advance new insight into the ways that consumers navigate the complexity of trying to live a sustainable lifestyle. In doing so, they challenge practitioners and scholars to explore the contexts of consumption that shape everyday habits but to recognize that it is not a static force; rather reflection on experience of interactions with aspects of the environment underpin continuous processes of change through which (un)sustainable consumption emerges.

The question of how to inform and create sustainable attitudes, commitments and lifestyles is one with which many in management education grapple. Preparing graduates to be promoters and enactors of responsible and sustainable business practices remains a challenge across the globe. Moosmayer et al. (2018) address this challenge by arguing that a normative paradox lies inherent in management education. They argue that, as a result of this paradox, even business schools with strongly proclaimed commitments to promoting the sustainability agenda fail to have the desired effect in terms of the graduates they deliver. How is it possible that so many business schools end up with a result that no-one considers ideal? Part of the explanation, the authors argue, is the result of the mental models based on outdated conceptions of agency and economic theory that persist in business schools. The authors however do not reach a fatalistic conclusion, but instead draw on Dewey's account of freedom to 
argue that critical reflection that envisages alternative social ends can inform new forms of habituation that may indeed support responsible and sustainable business practices.

The emphasis on the importance of reflection is continued in De Graaf's analysis of decision-making (2018) in professional practice. By analysing the behavioural approach of evidence-based management (EBMgt), it is argued that what counts as 'evidence' for practitioners can benefit from the tacit forms of orientation that 'craftmanship' affords professionals. The insights of Dewey and Aristotle are related to the business ethics literature on mental models to strengthen EBMgt's capacity to inform professional decisions. We come to understand how a specific way of knowing emerges professional praxis - one within which reflection is central, and where relational and development-oriented processes play a key role. The reflective practitioner is capable of integrating this form of knowing with more typical modes of scientific inquiry to bring decisions and behaviour in line with specific contexts and social goals. This kind of professional craftmanship is therefore more likely to support responsible and sustainable business.

The importance of relational, engaged processes of transacting is highlighted in Gillett et al. (2018), which examines a collaborative partnership between different types of enterprises to advance social goals. The rationale for such collaborations is predicated on the idea that processes and 'outcomes' can be improved when enterprises with different values, practices and resources come together. However, these differences inevitably introduce tensions into the working relationship. This article focuses upon a case study of the 'Empty Homes' initiative, which aims to restore the use of uninhabited dwellings. The paper draws upon a mixed method, longitudinal study to examine why and how hybrid organizations (social enterprises) collaborate with a local council to manage the initiative, exploring contrasting institutional logics that create tensions as these different types of organizations try to work together and the processes by which they are mitigated. They find that values, ethics, resource imbalances and ambitions for growth are central to the creation of tensions. Shared social mission, relationships amongst partners and an adaptive culture are key to easing the frictions experienced, alongside the reputational benefits and synergies that emerge through knowledge sharing and integration of other resources. Through this longitudinal case, the authors expose challenges to the rhetoric on collaborative enterprise. Their findings highlight that partners need to recognize from the outset that different values and mind-sets can create barriers to collaboration and that it is vital to facilitate relationships and evolve shared approaches to professional practice, if their collective pursuit of social value is to survive and flourish.

Retolaza et al. (2018) turn our attention to the opportunity to draw upon religious beliefs to construct meaning that leads to more ethical and sustainable business. This conceptual article highlights the compatibility of Catholic Social Thought and Stakeholder Theory but argues that current theorisation of Stakeholder Theory is limited in the approaches that have been espoused to evaluate the legitimacy of stakeholder interests and to determine priorities amongst them when their interests clash. They argue that the anthropological and ethical foundations of Catholic Social Thought afford a foundation from which to approach this evaluation and enhance business responsibility.

Osorio-Vega's analysis (2018) of social entrepreneurship debunks the assumed tension between social and economic value. A sensemaking approach to data gathered through an inductive study allows the authors to articulate the 'shared value' that is created through the activities of particular social entrepreneurs. The idiosyncratic imperatives that inform the social entrepreneurs' ongoing journey towards unified value are analysed in order to highlight the emerging ethical imperatives within three nascent British social ventures. Instead of portraying social and economic goals as dichotomous, the author argues that ethical groundings persist within a process of ongoing filtering. The importance of maintaining transparency in this process is central to allowing more inclusive social scrutiny to be maintained, leading to what business ethicists may describe as a strong form of relational accountability (Painter-Morland 2006; Painter-Morland et al. 2017).

Sewchurran et al. (2018) present a case study of a logistics company operating in an environment of historically poor returns on investment and pressure for short-term financial results. Frustration with managing in this context and concern that this environment might erode the customer value proposition prompted their exploration of how a business might prioritize its investment in intangibles to support sustainable value creation. Their study followed an inductive grounded theory approach and an exploration of the endemic short-termism experienced by the management team evolved through an iterative process to address the customer value proposition, the organization's capabilities and its system of investment in intangibles. The authors conclude that a focus on investment in intangible assets, introduced as a multi-year capabilities investment plan, can play a vital role in stimulating sustainable value creation. Their study led to investment in intangibles being approved by the company, leading them to conclude that long-term decision-making can co-exist in an environment of short-termism and low growth.

The process of 'knowing' through experimenting and a situated process of action is interrogated in the work by Davies and Doherty (2018), who investigate the difficulties of creating economic, social and environmental value when a company chooses to operate as a hybrid venture. Drawing on hybrid organizing and sustainable business model research and adopting a longitudinal case study 
approach, they explore the implications of alternative forms of business model used experimentally by Cafédirect, a farmer-owned, fair trade, social enterprise. The authors describe how, in seeking to deliver on all three forms of value capture (economic, social and environmental), the company tried multiple business model innovations in response to changes and challenges in the market and societal environment, meeting with varying levels of success. Through its exploration of normative understandings of integrating hybrid objectives and the complications of multiple types of value capture, their research adds to knowledge of how business models enact hybrid mission and provide a platform for triple bottom-line value capture.

We advance this special issue in a time when scholars and practitioners concerned with business ethics are highly sensitized to the sustainability issues associated with manifestations of capitalism across the industrialized world. Distinct risks, such as the driving forces of 'growthism' at the macro (national economy) and meso (company) levels, the short-term thinking (i.e. ever-faster product replacement) of consumerism (Schmelzer 2016; Jackson 2009; Hamilton 2010; Stahel 2006; Cooper 2005, 2010) and the inequity embedded within markets, are prominent. Thankfully, various moral and political dynamics have also stimulated initiatives to shape alternative forms of enterprise and markets that have a stronger ethical foundation, more legitimate processes governing fairness and equity, and effect developments such as the move from a linear economy of 'take, make and dispose' towards a circular one (Ellen MacArthur Foundation 2012; Ghisellini et al. 2016). Yet many questions remain about how this change will come about, hence the focus of our efforts here. We would like to express thanks to all authors who submitted to the SI who were willing to share their projects as part of this venture. The editorial team and a dedicated panel of reviewers were enthusiastic at the insight emerging from the papers and we thank the both the reviewing and authorial teams for their hard work in seeing the selected papers through to publication and enabling the special issue to come to fruition. We hope that you too will find that the SI provides interesting insights into the processes of transitioning towards ethical and sustainable business and consumption, that it will stimulate further research to explore how new forms of business emerge and invigorate debate on the ontological and epistemological assumptions that inform our ongoing journey of 'knowing'.

\section{Compliance with Ethical Standards}

Conflict of interest All authors declare that they have no conflict of interest.

\section{References}

Bang, H.-K., Ellinger, A. E., Hadjimarcou, J., \& Traichal, P. A. (2000). Consumer concern, knowledge, beliefs and attitude towards renewable energy: An application of the theory of reasoned action. Psychology and Marketing, 17(6), 449-469.

Bergson, H. (1965). Duration and simultaneity. Indianapolis: Bobbs-Merrill.

Bocken, N. M. P., Short, S. W., Rana, P., \& Evans, S. (2014). A literature and practice review to develop sustainable business model archetypes. Journal of Cleaner Production, 65, 42-56.

Brand, K.-W. (2010). Social practices and sustainable consumption: Benefits and limitations of a new theoretical approach. In M. Gross \& H. Heinrichs (Eds.), Environmental sociology: European perspectives and interdisciplinary challenges (pp. 217235). Dortrecht: Springer.

Cohen, M. (2007). Reading Dewey: Reflections on the study of routines. Organization Studies, 28, 773-787.

Cooper, T. (2005). Slower consumption: Reflections on product life cycles and the throwaway society. Journal of Industrial Ecology, 9(1-2), 51-67.

Cooper, T. (Ed.). (2010). Longer lasting products: Alternatives to the throwaway society. Abingdon: Routledge.

Davies, I., \& Doherty, B. (2018). Balancing a hybrid business model: The search for equilibrium at Cafédirect. Journal of Business Ethics. https://doi.org/10.1007/s10551-018-3960-9.

De Graaf, F. J. (2018). Ethics and behavioural theory: How do professionals assess their mental models? Journal of Business Ethics. https://doi.org/10.1007/s10551-018-3955-6.

De Pelsmacker, P., \& Janssens, W. A. (2007). A model for fair trade buying behaviour: The role of information and product-specific attitudes. Journal of Business Ethics, 75(4), 361-380.

Defourny, J., \& Nyssens, M. (2006). Defining social enterprise. In M. Nyssens (Ed.), Social enterprise: At the crossroads of market, public and civil society. London: Routledge.

Dewey, J. (1922 [1957]). Human nature and conduct. In J. A. Boydston (Ed.), Middle Works (p. 14). Carbondale: Southern Illinois University Press.

Dewey, J. (1939). Theory of valuation. International Encyclopedia of Unified Science, 2(4), 1-66.

Dewey, J. (1944). Some questions about value. The Journal of Philosophy, 41(17), 449-455.

Dubuisson-Quellier, S. (2013). A market mediation strategy: How social movements seek to change firms' practices by promoting new principles of product valuation. Organization Studies, 34(5-6), 683-703.

Ellen MacArthur Foundation (2012). Towards the circular economy vol 1: Economic and business rationale for an accelerated transition. Retrieved June 6, 2018, from https://www.ellenmacar thurfoundation.org/assets/downloads/publications/Ellen-MacAr thur-Foundation-Towards-the-Circular-Economy-vol.1.pdf

Fann, K. T. (2012). Pierce's theory of abduction. The Hague: Martinus NijHoff.

Ghisellini, P., Cialani, C., \& Ulgiati, S. (2016). A review on circular economy: The expected transition to a balanced interplay of environmental and economic systems. Journal of Cleaner Production, 114, 11-32.

Gillett, A., Loader, K., Doherty, B., \& Scott, J. M. (2018). An examination of tensions in a hybrid collaboration: A longitudinal study of an empty homes project. Journal of Business Ethics. https://doi.org/10.1007/s10551-018-3962-7.

Grosz, E. (2013). Habit today: Ravaisson, Bergson, Deleuze and us. Body and Society, 19(2\&3), 217-239. 
Hamilton, C. (2010). Consumerism, self-creation and prospects for a new ecological consciousness. Journal of Cleaner Production, $18,571-575$

Helgesson, C.-F., \& Kjellberg, H. (2013). Introduction: Values and valuations in market practice. Journal of Cultural Economy, 6(4), 361-369.

Helin, J., Hernes, T., Hjorth, D., \& Holt, R. (2014). The Oxford handbook of process philosophy and organization studies. Oxford: Oxford University Press.

Hiller, A. J., \& Woodall, T. (2018). Everything Flows: A pragmatist perspective of trade-offs and value in ethical consumption. Journal of Business Ethics. https://doi.org/10.1007/s1055 1-018-3956-5.

Jackson, T. (2009). Prosperity without growth: Economics for a finite planet. London: Earthscan.

Jacobs, D. C. (2004). A pragmatist approach to integrity in business ethics. Journal of Management Inquiry, 13(3), 215-233.

Jensen, T., \& Sandström, J. (2013). In defence of stakeholder pragmatism. Journal of Business Ethics, 114(2), 225-237.

Linder, M., \& Williander, M. (2015). Circular business model innovation: Inherent uncertainties. Business Strategy and the Environment, 26(2), 182-196.

Lorino, P. (2018). Pragmatism and organization studies. Oxford: Oxford University Press.

Marchand, A., Walker, S., \& Cooper, T. (2010). Beyond abundance: Self-interest motives for sustainable consumption in relation to product perception and preferences, Sustainability, 2, 1431-1447.

Moosmayer, D. C., Waddock, S., Wang, L., Huehn, M., Dierksmeier, C., \& Gohl, C. (2018). Leaving the road to Abilene: A pragmatic approach to addressing the normative paradox of responsible management education. Journal of Business Ethics. https://doi. org/10.1007/s 10551-018-3961-8.

Muniesa, F. (2011). A flank movement in the understanding of valuation. The Sociological Review, 59, 24-38.

Onyas, W. I., \& Ryan, A. (2014). Exploring the brand's world-asassemblage: The brand as a market shaping device. Journal of Marketing Management, 31(1-2), 141-166.

Osorio-Vega, P. (2018). The ethics of entrepreneurial shared value. Journal of Business Ethics. https://doi.org/10.1007/s1055 1-018-3957-4.

Painter-Morland, M. (2006). Triple bottom-line reporting as social grammar: Integrating corporate social responsibility and corporate codes of conduct. Business Ethics: A European Review, 15, 352-364.

Painter-Morland, M., Demuijnck, G., \& Ornati, S. (2017). Sustainable development and well-being: A philosophical challenge. Journal of Business Ethics, 146(2), 295-311.
Painter-Morland, M., Pouryousefi, S., Hibbert, S., \& Russon, J. A. (2018). Sharing vocabularies: Towards horizontal alignment of values-driven business functions. Journal of Business Ethics. https ://doi.org/10.1007/s10551-018-3901-7

Painter-Morland, M. J., \& Deslandes, G. (2014). Gender and visionary leading: Rethinking "identity" and "vision" with Deleuze and Bergson. Organization, 21(6), 844-866.

Ravaisson, F. (2008). Of habit. (C. Carlisle \& M. Sinclair, Trans.). New York: Continuum Press.

Retolaza, J. L., Aguado, R., \& Alcaniz, L. (2018). Stakeholder theory through the lenses of catholic social thought. Journal of Business Ethics. https://doi.org/10.1007/s10551-018-3963-6.

Sewchurran, K., Dekker, J., \& McDonogh, J. (2018). Experiences of embedding long-term thinking in an environment of short-termism and sub-par business performance: Investing in capabilities for sustainable growth. Journal of Business Ethics. https://doi. org/10.1007/s10551-018-3959-2.

Schmelzer, M. (2016). The hegemony of growth: The OECD and the making of the economic growth paradigm. Cambridge: Cambridge University Press.

Shaw, D., \& Riach, K. (2011). Embracing ethical fields: Constructing consumption in the margins. European Journal of Marketing, 45(7/8), 1051-1067.

Stahel, W. R. (2006). The performance economy. Basingstoke: Palgrave Macmillan.

Visser, M. (2017). Pragmatism, critical theory and business ethics: Converging lines. Journal of Business Ethics. https://doi. org/10.1007/s10551-017-3564-9.

Walther, C. S., \& Sandlin, J. A. (2013). Green capital and social reproduction within families practising voluntary simplicity in the US. International Journal of Consumer Studies, 37, 36-45.

Werhane, P. H. (2008). Mental models, moral imagination and systems thinking in an age of globalization. Journal of Business Ethics, $78(3), 463-474$.

Winter, S. (2013). Habit, deliberation, and action: Strengthening the microfoundations of routines and capabilities. Academy of Management Perspectives, 27(2), 120-137.

Woolsey Biggart, N., \& Beamish, T. D. (2003). The economic sociology of convensions: Habit, custom, practice and routine in market order. Annual Review of Sociology, 29, 443-464.

York, G. J. (2009). Pragmatic sustainability: Translating environmental ethics into competitive advantage. Journal of Business Ethics, 85(1), 97-109. 